\title{
Olga Anisimova
}

Ph. D. (Economics), SSI «Institute of Educational Analytics», Kyiv, Ukraine, olgaanisimova@ukr.net ORCID ID: https://orcid.org/0000-0002-6721-3030

\section{IMPLEMENTING QUALITY ASSESSMENT OF HIGHER EDUCATION ACCORDING TO THE STANDARDS AND GUIDELINES FOR QUALITY ASSURANCE IN THE EUROPEAN HIGHER EDUCATION AREA (ESG): BEST PRACTICES}

\begin{abstract}
The article examines the Standards and Guidelines for Quality Assurance in the European Higher Education Area (ESG) and their implementation for external quality assessment of higher education. An analysis of the activities of agencies to assess the quality of education, the main forms and tools of its implementation are carried out. It is established that the ESG were adopted in 2005 by the Ministers responsible for higher education. The ESG have been constantly revised and improved, and the version adopted in 2015 is currently in force. They consist of three parts: standards and recommendations for internal quality assurance (10 items); standards and recommendations for external quality assurance (7 items); standards and recommendations for quality assurance agencies ( 7 items). In the framework of the Bologna Process, since 2003 it has been determined that the main responsibility for the quality of higher education services lies with the HEIs themselves, which conduct the internal quality assessment, i.e. they implement a set of measures and procedures to ensure the quality of proposed educational programs and services. Certain criteria, which are determined both by the HEI itself and by the agencies for assessing the quality of education are used. The main function of external assessment of the quality of education is to provide feedback and recommendations to the HEIs and objective and unbiased information to stakeholders. The principles, procedures and criteria for assessing the quality of education should apply to all methods of providing educational services and teaching. It should be noted that the ESG are not quality standards as such, they do not define quantitative criteria or regulate the implementation process, they are guidelines that define the main areas that need special attention to ensure quality services and create a favorable educational environment.
\end{abstract}

Keywords: Standards and Guidelines for Quality Assurance in the European Higher Education Area (ESG), higher education quality assessment, internal education quality assessment, external education quality assessment, education quality assessment agencies, European approach.

JEL classification: I21, I23.

DOI: $10.32987 / 2617-8532-2020-4-83-92$.

The need to adopt common standards for quality assurance of education within the European Higher Education Area is due to the high mobility of the workforce and the need to create common approaches to the recognition of degrees and diplomas obtained in different countries. In addition to internal quality assurance, the standards for the European Higher Education Area also provide for external evaluation. Since 2003, it has been determined in

(C) Анісімова О. Ю., 2020 
the framework of the Bologna Process that the main responsibility for the quality of higher education services lies within the HEIs themselves, which conduct internal quality assurance, i.e. they implement a set of measures and procedures to ensure the quality of proposed educational programs and compliance with certain criteria, which are determined both by the HEI itself and by education quality assurance agencies.

Standards and Guidelines for Quality Assurance in the European Higher Education Area (ESG) were adopted in 2005 by the Ministers responsible for higher education on a proposal prepared by the European Association for Quality Assurance in Higher Education (ENQA) in collaboration with the European Students Union (ESU), the European Association of Institutions in Higher Education (EURASHE) and the European University Association (EUA). Since 2005, significant progress has been made in quality assurance, as well as in other areas of the Bologna Process, such as qualifications frameworks, recognition of qualifications and promotion of learning outcomes, which are oriented towards student-centered teaching and learning.

The main function of the external evaluation of the quality of education is to provide feedback and recommendations to the HEIs and objective and unbiased information to stakeholders. The principles, procedures and criteria for assessing the quality of education should apply to all methods of providing educational services and teaching. It should be noted that ESG are not quality standards as such, they do not define quantitative criteria or regulate the implementation process, they are guidelines that define the main areas that need special attention to ensure quality services and create a favorable educational environment [1].

Thus, the ESG is the basis for the implementation of quality assurance in the European Higher Education Area, and the national ministries responsible for higher education use it to develop national approaches to quality assessment. For external quality control of higher education, national education quality assurance agencies are established, which are usually accredited by the European Association for Educational Quality Assurance, which increases the level of cross-border recognition of national diplomas, facilitates academic mobility and simplifies enrollment.

Over time, the procedure for external quality assessment became more complex. Currently, agencies have several types of evaluation procedures: evaluation of each individual program, cluster evaluation, an audit of quality systems, review of individual faculties and HEIs in general, and so on. Despite significant progress in this area, some problems continue to arise in the process of quality assurance, especially when it comes to its consistency between agencies in different countries. The main problem remains, it's about the disagreement about what to consider quality. Among the criteria often used are excellence, compliance with the thresholds of the criteria, the potential for transformation, compliance with the goals, transparency and accountability. As a result, national agencies are sometimes forced to change criteria according to the policies of their governments. As a result, in many countries, there is a constant process of 
procedural changes or reorganization of agencies. The most popular evaluation criteria today are the quality of teaching and learning, institutional risks and employment of graduates [2].

According to experts, especially the representatives of international organizations, the agencies do not always take into account all the necessary aspects, and some criteria are very difficult to quantify. Moreover, they emphasize that it is almost impossible to quantify the long-term consequences of external quality assurance. As a result, the only way is to gradually build a culture of quality of institutions through constant interaction between internal and external quality assurance. Very often this does not happen for political reasons.

According to the level of implementation of the main components of external quality assurance within the ESG for the European Higher Education Area, there are four main groups of countries.

1. Countries with a highly developed, fully functional quality assurance system, in which all higher education institutions undergo a continuous and regular external evaluation procedure by an agency that successfully complies with all ESG procedures and standards by registering in the European Register of Quality Assurance (EQAR). This group of countries includes Armenia, Austria, Belgium, Bulgaria, Croatia, Cyprus, Denmark, Estonia, Finland, France, Georgia, Germany, Hungary, Ireland, Kazakhstan, Latvia, Liechtenstein, Lithuania, Luxembourg, the Netherlands, Poland, Norway, Romania, Slovenia, Spain, Switzerland, Great Britain. As you can see from this list, this includes not only developed countries with a long tradition of wellknown HEIs, but also the countries of Central and Eastern Europe, which have only recently joined the competitive market of educational services [3; 4].

For example, the United Kingdom joined the EQAR in 2014. In this country, the external assessment of the quality of education takes place at the level of higher education institutions, and the HEIs cannot choose the agency that will conduct their evaluation, this is regulated at the legislative level. On the other hand, for the joint educational programs, the HEIs can apply the socalled European approach to external evaluation. All HEIs accredited by the relevant agency may establish their own diplomas in accordance with the national law [5].

In turn, Poland has been a member of the EQAR since 2008. Higher education institutions in this country include two types of institutions - university and non-university. In 2012-2016, the assessment was conducted at the level of the higher educational institutions, after the relevant amendments to the Law on Higher Education, the evaluation at the level of institutions is no longer conducted, and evaluation criteria were introduced at the level of individual educational programs. As a result of the assessment, 4 possible levels can be obtained: impeccable (valid for 8 years), positive (for 6 years), conditional (with the date of the next revaluation) and negative. The HEIs may independently select an agency to conduct an external assessment, provided that it is a member of the EQAR. An external evaluation is also required to open a postgraduate and doctoral program. Foreign HEIs can open branches in Poland, provided that they have been accredited by any 
agency registered with the EQAR. The European approach can be used when evaluating joint educational programs [6].

Among the Scandinavian countries, this group includes Norway, which has been a member of the EQAR since 2008. Higher education can be obtained at universities, specialized university institutions, university colleges, university art colleges, other public university colleges that are not accountable to the Ministry of Education and Science, and private HEIs. The system of higher education consists of three cycles, except for some short programs. In 2010, the basic principles for assessing and developing the quality of higher education and vocational education were defined by the law. At the initial stage, universities and colleges are accredited at the institutional level and receive the right to issue national diplomas. After that, universities and specialized university institutions receive the right to selfaccreditation of certain educational programs. University colleges are eligible for self-accreditation of undergraduate programs but must receive external accreditation for masters and postgraduate programs. University colleges that do not have institutional accreditation must accredit each educational program separately. External accreditation at the level of the HEIs is conducted every eight years. The HEIs do not choose the agency that will conduct the evaluation independently. The European approach to the evaluation of joint programs can be used only by those HEIs who do not have to accredit each program separately [7].

2. Countries that have a fully functional quality assurance system, however, undergo only a regular external evaluation by an agency that successfully complies with all ESG procedures and standards by registering in the European Quality Assurance Register for Higher Education (EQAR). This group of countries includes the Czech Republic, Greece, the Vatican, Iceland, Italy, Moldova, Montenegro, Russia, Serbia, Slovakia, Sweden, and Turkey [3].

For example, Italy joined the EQAR only in 2018. Higher education in Italy can be obtained at universities (including polytechnics), art and music HEIs, higher language schools, higher technical institutions. Assessment of the quality of education takes place at two levels: internal (conducted by the HEIs themselves) and external (National Agency for Quality Assurance in Education). The National External Evaluation System was introduced in 2013 (as amended in 2016) and provides for: (1) accreditation at the level of the HEIs, which is conducted every 5 years; (2) program-level accreditation conducted every three years. The European approach to joint programs is not applied in the country [8].

On the other hand, Sweden is not a member of the EQAR at all, although it uses certain ESG. Higher education in the country can be obtained in state universities and state university colleges, as well as in some private HEIs that have received the appropriate accreditation. All HEIs undergo an external evaluation at the level of institutions and a separate evaluation of each program. This is done only by the national agency, as a result, the European approach cannot be used when evaluating joint programs [9].

The Czech Republic joined the EQAR in 2013. The HEIs in this country can 
be public, state and private. According to the Law on Higher Education, the HEIs can be of the university type (they offer educational programs at all three levels of higher education) and of the non-university type (they offer mainly bachelor's programs). Each HEI must have its own internal quality assessment system. External evaluation of the HEIs and educational programs they offer is carried out by the Accreditation Commission of the Czech Republic. Accreditation of educational programs is carried out for a period of up to 10 years, if you are refused accreditation, the next attempt may be only after 2 years. Accreditation of the HEIs is granted for 5 (if it is a second attempt) or 10 years. If the accreditation is carried out in a certain field of science, the HEIs can independently open several educational programs within this field. The HEIs may be accredited by a foreign agency that is a member of the EQAR, however, its results must be approved by the Accreditation Commission at the national level. The European approach cannot be used when evaluating joint programs [10].

3. Countries with a national education quality assurance system but are not yet fully compliant with the ESG principles. Such countries include Albania, Andorra, Azerbaijan, Bosnia and Herzegovina, Malta, Northern Macedonia, and Ukraine [3].

In particular, Azerbaijan joined the EQAR in 2015. Higher education in this country can be obtained from public or private HEIs, which are accountable to the Ministry of Education and other overseeing bodies. Each HEI must obtain a permit to provide educational services. The decision on accreditation is made by the Accreditation Council, headed by the Minister of Education, on the basis of certain requirements and criteria. Accreditation takes place every 5 or 3 years (in the case of foreign HEIs). The HEIs cannot select an agency from the EQAR list and cannot use the European approach to joint programs [11].

4. Countries that do not have a system of quality assurance in education. Currently, only Belarus belongs to this group [3].

The ultimate goal of the comprehensive implementation of the ESG is the general recognition of the quality assurance agencies included in the EQAR in all countries of the European Higher Education Area so that the HEIs are free to choose the agency at their discretion from among the accredited. As a result, it is believed that this will increase the level of recognition of national diplomas and qualifications in other countries, as well as create a European dimension of quality assurance.

Currently, the degree of recognition of foreign quality assessment agencies in different European countries varies. There are three main groups of countries.

1. Countries that recognize EQAR-registered agencies as part of national requirements for external quality assurance in education. These countries include Armenia, Austria, Belgium, Bulgaria, Cyprus, Finland, Germany, Hungary, Kazakhstan, Latvia, Liechtenstein, Lithuania, Luxembourg, Moldova, Poland, Romania, Slovakia, Switzerland, and Ukraine.

2. Countries that recognize individual foreign agencies, but have their own requirements and criteria for them. These countries include Albania, the Czech Republic, Denmark, Estonia, 
France, Georgia, Malta, Montenegro, the Netherlands, Portugal, and Turkey.

3. Countries that do not recognize foreign agencies as part of the national system of external quality assurance of education. These countries include Andorra, Azerbaijan, Belarus, Bosnia and Herzegovina, Croatia, Greece, the Vatican, Iceland, Ireland, Northern Macedonia, Norway, Russia, Serbia, Slovenia, Spain, Sweden, and the United Kingdom [12].

It should be noted that the recognition of foreign agencies in the national system is not the main criterion for dividing countries into groups according to the level of implementation of the ESG.

Recently, in the European Higher Education Area, joint programs, which are being developed by HEIs from different countries, have become increasingly popular. They are designed to stimulate the mobility of students and teachers, share experiences and create long-term cooperation to improve the quality of educational programs offered. One of the conditions for the existence of such programs is the issuance of a joint or double diploma. At the same time, the implementation of joint programs is hampered by serious problems, especially the issue of recognition and quality assurance, as different countries have their own accreditation requirements and recognition criteria, which can sometimes contradict each other. As a result, a European approach to quality assurance of joint programs has been established, which sets common standards based on defined criteria that do not take into account national standards [4].

The European approach is applied in the following cases:
(1) If the HEIs creating a joint program requires an external quality assessment at the level of educational programs, the relevant agency should be selected from the EQAR list for further evaluation.

(2) The selected agency, guided by parts $\mathrm{B}$ and $\mathrm{C}$ of the ESG, conducts one evaluation or accreditation of the entire joint program, the results of which are recognized in all EHEA countries; these results are also recognized at the national level in the countries where the program is proposed.

(3) No additional assessment or accreditation is required. The offered program can be joined by the HEIs of non-EHEA countries, however, such HEIs must make sure that the results of such accreditation will be recognized at their national level [4].

At this stage, European countries are at different steps of implementation of the European approach. There are three main groups of countries.

1. Countries in which the European approach can be applied by all the HEIs. Such countries include Armenia, Belgium, Bulgaria, Denmark, Finland, Hungary, Kazakhstan, Liechtenstein, Lithuania, Malta, Moldova, the Netherlands, Poland, Switzerland, and the United Kingdom.

2. Countries in which the European approach can be used only by certain HEIs, or in which special requirements for its application are established. These countries include Austria, Bosnia and Herzegovina, Cyprus, Estonia, France, Georgia, Germany, Ireland, Luxembourg, Norway, Portugal, Russia, Serbia, Slovenia, and Spain.

3. Countries where the European approach cannot be used. These countries include Albania, Andorra, 
Azerbaijan, Belarus, Croatia, Czech Republic, Greece, Vatican, Iceland, Italy, Latvia, Montenegro, Northern Macedonia, Romania, Slovakia, Sweden, Turkey, Ukraine [13].

Thus, it can be concluded that currently, countries are in no hurry to abandon the establishment of national criteria for the accreditation of educational programs, so progress in this direction is quite slow.
Since 2014, there has been a gradual increase in the number of quality assurance agencies included in the EQAR (Fig. 1).

Also, there is a certain increase in the number of evaluations of the proposed programs, the HEIs as institutions and joint programs (Fig. 2).

The vast majority of assessments were conducted at the level of individual educational programs, while

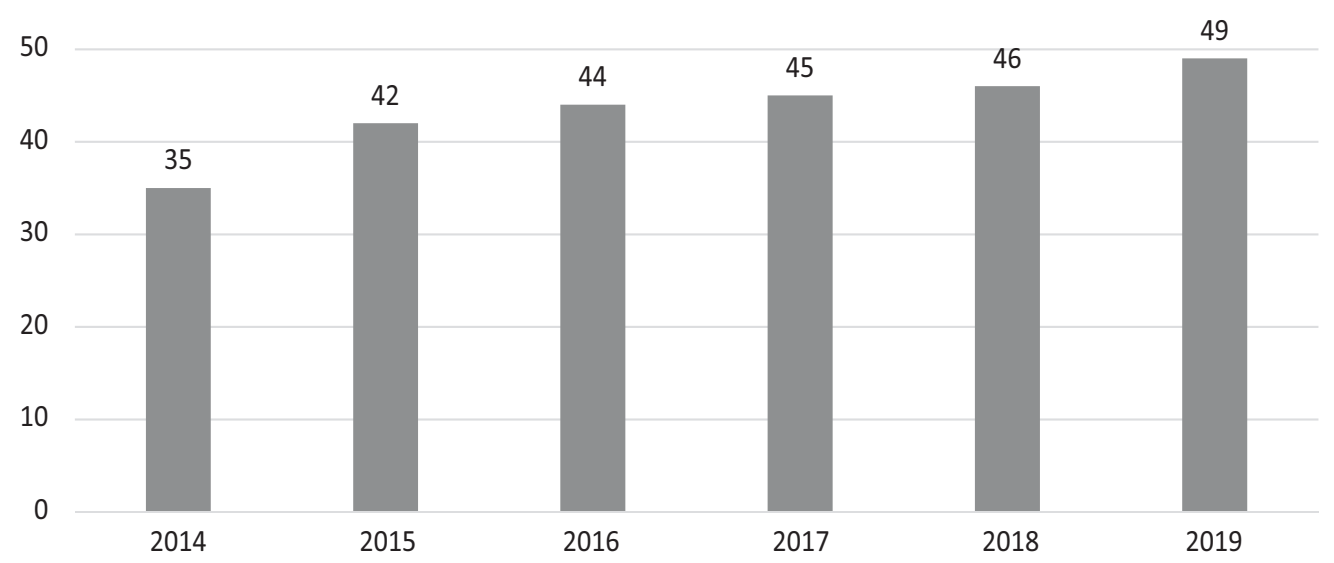

Fig. 1. Number of education quality assurance agencies registered with the EQAR in 2014-2019

Complied by the author based on data from the EQAR. URL: https://www.eqar.eu/kb/ external-qa-activities/\#some-key-take-aways-from-the-policy-brief.

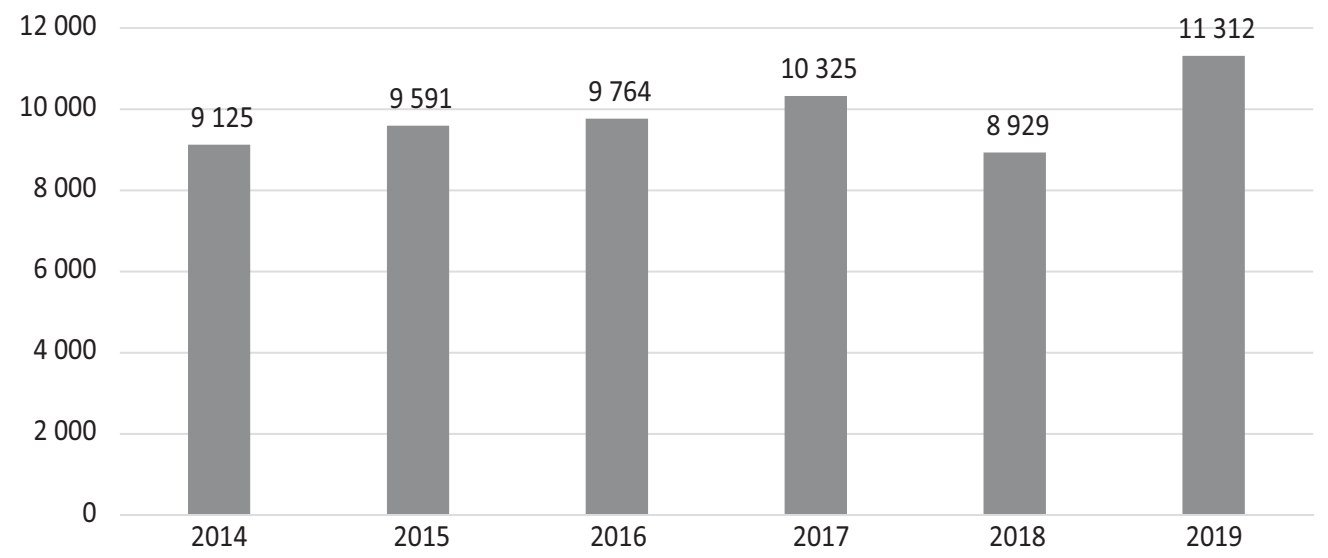

Fig. 2. Number of evaluations conducted by education quality assurance agencies registered with the EQAR in 2014-2019

Complied by the author based on data from the EQAR. URL: https://www.eqar.eu/kb/ external-qa-activities/\#some-key-take-aways-from-the-policy-brief. 
the share of assessments at the level of the HEIs and joint programs remained consistently low. This indicates the transition of most EHEA countries to a more individualized approach and reduced autonomy of the HEIs in some countries.

Conclusions. The need to adopt common standards for quality assurance of education within the European Higher Education Area is due to the high mobility of the workforce and the need to create common approaches to the recognition of degrees and diplomas obtained in different countries. In addition to internal quality assurance, the standards for the European Higher Education Area also provide for external evaluation.

The main function of the external evaluation of the quality of education is to provide feedback and recommendations to the HEIs and objective and unbiased information to stakeholders. The principles, procedures and criteria for assessing the quality of education should apply to all methods of providing educational services and teaching.

Over time, the procedure for external quality assessment became more complex. Currently, agencies have several types of evaluation procedures: evaluation of each individual program, cluster evaluation, the audit of quality systems, review of individual faculties and HEIs in general, and so on. Despite significant progress in this area, some problems continue to arise in the process of quality assurance, especially when it comes to its consistency between agencies in different countries. The main problem remains, it's about the disagreement about what to consider quality. Among the criteria often used are excellence, compliance with the thresholds of the criteria, the potential for transformation, compliance with the goals, transparency and accountability.

The ultimate goal of the comprehensive implementation of the ESG is the general recognition of the quality assurance agencies included in the EQAR in all countries of the European Higher Education Area so that the HEIs are free to choose the agency at their discretion from among the accredited. As a result, it is believed that this will increase the level of recognition of national diplomas and qualifications in other countries, as well as create a European dimension of quality assurance.

Recently, in the European Higher Education Area, joint programs, which are being developed by HEIs from different countries, have become increasingly popular. They are designed to stimulate the mobility of students and teachers, share experiences and create long-term cooperation to improve the quality of educational programs offered. As a result, a European approach to quality assurance of joint programs has been established, which sets common standards based on defined criteria that do not take into account national standards.

\section{References}

1. EQAR. (n. d.). QA in Europe. Retrieved from https://www.eqar.eu/kb/external-qaactivities/.

2. EQAR. (2020, June). Policy Brief 2020. External Quality Assurance Activities within and beyond the EHEA. Retrieved from https://www.eqar.eu/assets/uploads/2020/07/Policy Brief_EQA_WithinandBeyondEHEA.pdf. 
3. EQAR. (n. d.). Country information. Retrieved from https://www.eqar.eu/kb/countryinformation/.

4. EQAR. (n. d.). European Approach for Quality Assurance of Joint Programmes Application. Retrieved from https://www.eqar.eu/kb/joint-programmes/application/.

5. EQAR. (n. d.). Country information. United Kingdom. Retrieved from https://www.eqar. $\mathrm{eu} / \mathrm{kb} /$ country-information/country/?id=183.

6. EQAR. (n. d.). Country information. Poland. Retrieved from https://www.eqar.eu/kb/ country-information/country/?id=138.

7. EQAR. (n. d.). Country information. Norway. Retrieved from https://www.eqar.eu/kb/ country-information/country/?id=129.

8. EQAR. (n. d.). Country information. Italy. Retrieved from https://www.eqar.eu/kb/ country-information/country/?id=82.

9. EQAR. (n. d.). Country information. Sweden. Retrieved from https://www.eqar.eu/kb/ country-information/country/?id=166.

10. EQAR. (n. d.). Country information. Czech Republic. Retrieved from https://www.eqar. $\mathrm{eu} / \mathrm{kb} /$ country-information/country/?id=46.

11. EQAR. (n. d.). Country information. Azerbaijan. Retrieved from https://www.eqar.eu/ $\mathrm{kb} /$ country-information/country/?id=11.

12. EQAR. (n. d.). Cross-Border Quality Assurance in the EHEA. Retrieved from https:// www.eqar.eu/kb/cross-border-qa/.

13. EQAR. (n. d.). National Implementation of the European Approach. Retrieved from https://www.eqar.eu/kb/joint-programmes/national-implementation/.

\section{Анісімова О. Ю.}

кандидат економічних наук, старший науковий співробітник сектору аналізу фінансування освіти відділу статистики та аналітики освіти ДНУ «Інститут освітньої аналітики», Київ,

Україна, olgaanisimova@ukr.net

ORCID ID: https://orcid.org/0000-0002-6721-3030

\section{СВІТОВИЙ ДОСВІД ОЦІНКИ ЯКОСТІ ВИЩОЇ ОСВІТИ ВІДПОВІДНО ДО СТАНДАРТІВ І РЕКОМЕНДАЦІЙ ЩОДО ЗАБЕЗПЕЧЕННЯ ЯКОСТІ В ЄВРОПЕЙСЬКОМУ ПРОСТОРІ ВИЩОЇ ОСВІТИ (ЕSG)}

Анотація. У статті розглянуто стандарти й рекомендації щодо забезпечення якості в Європейському просторі вищої освіти (ESG) з точки зору їх імплементації для проведення зовнішнього оцінювання якості вищої освіти. Проаналізовано діяльність агенцій з оцінки якості освіти, її основні форми та інструменти. Зазначено, що ESG були прийняті у 2005 р. міністрами, котрі відповідають за вищу освіту. В рамках Болонського процесу ще у 2003 р. було встановлено, що за якість наданих послуг вищої освіти відповідають передусім самі 3ВО, які здійснюють їі внутрішнє оцінювання, тобто забезпечують комплекс заходів і процедур, котрі гарантують якість запропонованих освітніх програм та відповідність наданих послуг певним критеріям, що визначаються як самим 3ВО, так і агенціями з оцінки якості освіти. Основною функцією 
ї̈ зовнішнього оцінювання є надання ЗВО відгуків і рекомендацій, а також об'єктивної та неупередженої інформації зацікавленим особам. Принципи, процедури й критерії оцінювання якості освіти повинні застосовуватися щодо всіх способів надання освітніх послуг і форм викладання.

Ключові слова: стандарти та рекомендації щодо забезпечення якості в Європейському просторі вищої освіти (ESG), оцінювання якості вищої освіти, внутрішнє оцінювання якості освіти, зовнішнє оцінювання якості освіти, агенції з оцінки якості освіти, європейський підхід..

\section{Список використаних джерел}

1. QA in Europe. EQAR. URL: https://www.eqar.eu/kb/external-qa-activities/ (Accessed 20.11.2020).

2. Policy Brief 2020. External Quality Assurance Activities within and beyond the EHEA. (2020, June). EQAR. URL: https://www.eqar.eu/assets/uploads/2020/07/PolicyBrief_EQA_ WithinandBeyondEHEA.pdf (Accessed 20.11.2020).

3. Country information. EQAR. URL: https://www.eqar.eu/kb/country-information/ (Accessed 20.11.2020).

4. European Approach for Quality Assurance of Joint Programmes Application. EQAR. URL: https://www.eqar.eu/kb/joint-programmes/application/ (Accessed 20.11.2020).

5. Country information. United Kingdom. EQAR. URL: https://www.eqar.eu/kb/countryinformation/country/?id=183 (Accessed 20.11.2020).

6. Country information. Poland. EQAR. URL: https://www.eqar.eu/kb/countryinformation/country/?id=138 (Accessed 20.11.2020).

7. Country information. Norway. EQAR. URL: https://www.eqar.eu/kb/countryinformation/country/?id=129 (Accessed 20.11.2020).

8. Country information. Italy. EQAR. URL: https://www.eqar.eu/kb/country-information/ country/?id=82 (Accessed 20.11.2020).

9. Country information. Sweden. EQAR. URL: https://www.eqar.eu/kb/countryinformation/country/?id=166 (Accessed 20.11.2020).

10. Country information. Czech Republic. EQAR. URL: https://www.eqar.eu/kb/countryinformation/country/?id=46 (Accessed 20.11.2020).

11. Country information. Azerbaijan. EQAR. URL: https://www.eqar.eu/kb/countryinformation/country/?id=11 (Accessed 20.11.2020).

12. Cross-Border Quality Assurance in the EHEA. EQAR. URL: https://www.eqar.eu/kb/ cross-border-qa/ (Accessed 20.11.2020).

13. National Implementation of the European Approach. EQAR. URL: https://www.eqar. $\mathrm{eu} / \mathrm{kb} /$ joint-programmes/national-implementation/ (Accessed 20.11.2020). 